\title{
Is the Recent Increasing Trend of Rainfall over Northeast Brazil Related to Sub-Saharan Drought?
}

\author{
V. Brahmananda Rao, Emanuel Giarolla, mary T. Kayano, and Sergio H. Franchito \\ Centro de Previsão de Tempo e Estudos Climáticos, CPTEC Insituto Nacional de Pesquisas Espaciais, São Insé dos Campos, \\ Sao Paolo, Brazil
}

(Manuscript received 8 July 2005 . in final lorm 14 December 2005)

\begin{abstract}
ABSTR $\Lambda C T$
In recent years, there has been an increase in rainfall over northeast Brazil (Nordeste), while over the sub-Saharan region there has been a drought. The correlation coefficients between the 11 -yr running means of the rainfall series over the two regions are significant (at the $95 \%$ confidence level by a two-sided $t$ test), suggesting that both trends are related. The rainfall variations over the two regions are connected to the position of the intertropical convergence zone (ITCZ) over the Atlantic. A more southward (northward) position of the ITCZ is favorable for higher than normal rainfall over Nordeste (sub-Sahara). The correlation coefficient between the position of the ITCZ over the Allantic and the rainfall over Nordeste (sub-Sahara) is negative (positive) and highly significant, reaching values over 0.9. Thus, this study suggests that a more southward than normal location of the IIC $Z$ in the Atlantic may be the cause for the recent increasing (decreasing) trend of rainlall over Nordeste (sub-Sahara).
\end{abstract}

\section{Introduction}

As early as 1928 , the rainfall variations over semiarid northeast Brazil (Nordeste) attracted scicntists' attention (Walker 1928). Trewartha (1961) termed the climate of this region as one of the "Earth's problem climates." Recent studies improved the knowledge of this region's climate; nevertheless, the accurate prediction of rainfall over this region is still a scientific challenge (Hastenrath 1995; Moura and Hastenrath 2004). Another region of "Earth's problem climates" is subSaharan Africa (Trewartha 1961). The continuing drought conditions in this region led to intense human suffering and the causes for the persistence of drought are not yet understood (Dai et al. 2004). Hastenrath and Heller (1977) were the first to show that the rainfall variations over the Nordeste are strongly connected to the position of the intertropical convergence zone (ITCZ) in the Atlantic. The brief rainfall season of

Corresponding author address: Dr. V. B. Rao. Contro de Previsão de Tempo e Estudos Climáticos, CPTEC Instituto Nacional de Pesquisas Fspaciais, INPE (P 515, 12245-970, São José dos Campos, SP, Brazil.

E-mail: vbrao@cptec.inpe.br
March, April. and May (MAM) coincides with the southernmost position of the ITCZ in the Atlantic. A more southward than normal position of the ITCZ is favorable for higher rainfall over Nordeste and the rainfall over sub-Sahara is also connected to the ITCZ (Hastenrath 1995).

Two of the basic mechanisms that cause rainfall variations in the Tropics are the Walker and Hadley circulations. Zonally averaged motions in the meridional plane are the pure Hadley circulations. Deviations from these zonally averaged motions are associated with pure Walker circulations (Rao et al. 2004). However, local vertical motions, which cause rainfall variations, have both the Walker and Hadley modes. Moura and Shukla (1981) and Hastenrath and Greischar (1993) showed the importance of local meridional circulations on Nordeste rainfall. Stoeckenius (1981) suggested the role of Walker circulations in the tropical precipitation variations. The position of the ITCZ is crucial to the rainfall of the Nordeste and sub-Sahara and the circulation associated with the ITCZ has the influence of both the Walker and Hadley circulations.

A few studies have been conducted regarding the long-term variations of rainfall over the Nordeste. Wagner (1996) noted a decadal trend of interhemi- 


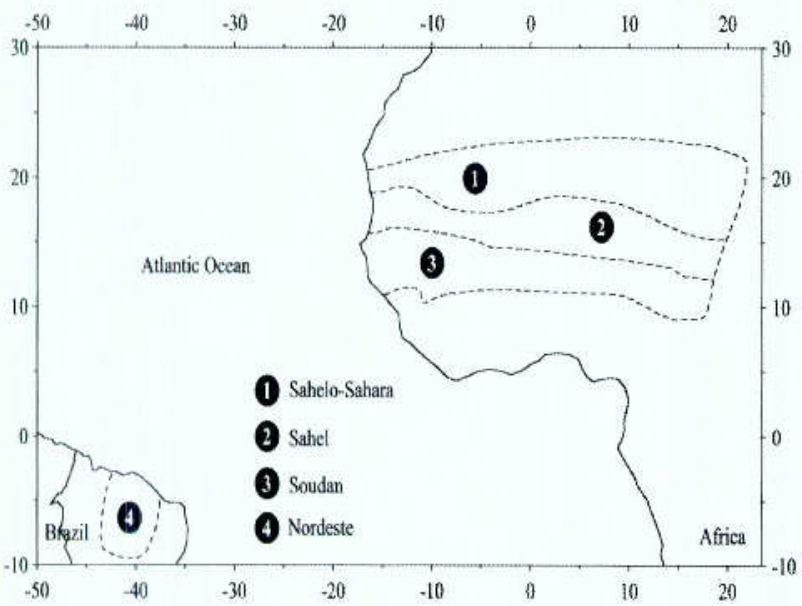

FIG. I. Locations of Nordeste and sub-Saharan regions.

spheric sea surface temperature (SST) gradient in association with a strong increase in South Atlantic SSTs centered at $20^{\circ}-30^{\circ} \mathrm{S}$ in summer. He found a positive correlation between this SST trend and precipitation anomalies over Nordeste and suggested that the cause for this positive correlation is the southward displacement of the ITCZ. Using a small number of rain gauge stations. Marengo et al. (1998) also noted a slow increase in rainfall over Nordeste. However, this study is not conclusive and they noted the need to extend it with more rain gauge stations. Hastenrath (2000) presented the upper-level circulation changes associated with the increase in precipitation over Nordeste. Kayano and Andreoli (2004) found a decadal relationship between the northern Nordeste rainfall and the SST anomalies in the tropical Pacific occurring through the Northern Hemisphere (NH) midlatitudes, including variations in the North Atlantic Oscillation system and SST variations in the tropical North Atlantic. Consistently, Paegle and Mo (2002) showed that a rainfall mode with the largest anomalies over Nordeste is influenced by the North Atlantic Oscillation on a decadal time scale.

The two regions, namely Nordeste and sub-Sahara, are separated by a short distance of about $3000 \mathrm{~km}$ and thus may influence the rainfall distribution of each other. Figure 1 illustrates the locations of these regions. Indeed, in a recent numerical study, Cook et al. (2004) noted the mutual influence of the South American and African continents on precipitation distributions. Here we study the rainfall variations over Nordeste and subSahara in recent years and the possible interrelation between them.

\section{Data and methods}

Normalized rainfall departures for Nordeste were obtained for 61 stations given in Rao et al. (1995) and updated in Rao et al. (1999). Initially, means and standard deviations were determined for each station. Then the departures of individual years were expressed in terms of standard deviations. All station averages form the normalized rainfall departures. Normalized annual rainfall departures for sub-Sahara were obtained from Nicholson (1994). The procedure to obtain the annual rainfall departures for sub-Sahara is the same as the one used by Rao et al. $(1995,1999)$. In this study, we used 11-yr running averages to remove interannual and decadal fluctuations. For the Nordeste, Sahel, and Soudan and Sahelo-Sahara regions, rainfall series are available, respectively, from 1912-95, 1901-90, and 1921-90.

Monthly reanalyzed 1000 -hPa zonal and meridional winds, sea level pressure, and $850-\mathrm{hPa}$ vertical velocity data for the period from 1949 to 2003 are also used. These data were produced by the Climate Data Assimilation System (CDAS) Reanalysis Project (Kalnay et al. 1996) and have a resolution of $2.5^{\circ}$ in latitude and longitude. Analyses of the reanalyzed data are done for the tropical band between $70^{\circ} \mathrm{W}$ and $20^{\circ} \mathrm{E}$.

The reanalyzed data are used to examine long-term trends in some atmospheric parameters. This is done by calculating the differences between 21 -yr average fields centered in 1990 and in 1959 for the February-May (FMAM) and June-August (JJA) periods. In addition, the trends in sea level pressure over sub-Sahara and Nordeste are calculated for the period 1949 through 2003 . For this, small areas over sub-Sahara $\left(10^{\circ}-20^{\circ} \mathrm{N}\right.$, $\left.0^{\circ}-20^{\circ} \mathrm{E}\right)$ and Nordeste $\left(12^{\circ}-3^{\circ} \mathrm{S}, 42^{\circ}-34^{\circ} \mathrm{W}\right)$ are selected. In addition, as the rainfall in the Nordeste and sub-Saharan regions is modulated by the position of the ITCZ, a time series of the latitudinal position of the ITCZ at $30^{\circ} \mathrm{W}$ is constructed. Following Uvo (1989) and Nobre and Shukla (1996), the ITCZ position is determined as the latitude where the meridional wind vanishes. The ITCZ position time series are obtained for the period 1948-95. Another way of obtaining the position of ITCZ is based on cloudiness. However, satellite data are available only from 1979 , which is a limitation for the present study.

Correlation coefficients between the Nordeste rainfall time series and the sub-Saharan rainfall time series, as well as between the Nordeste rainfall and subSaharan rainfall time series and the ITCZ position, are calculated. To assess the statistical significance of the correlation coefficient, the number of degrees of freedom is estimated using the method of Zhang and Hendon (1997). The number of degrees of freedom is the total number of years in a time series divided by $11 \mathrm{yr}$ (the period considered for the running mean). 


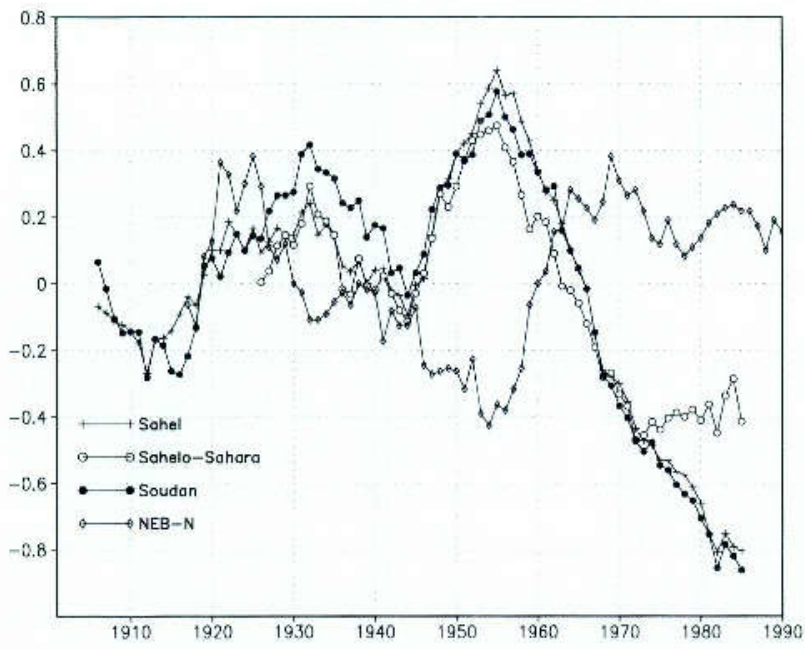

FIG. 2. Time variation of normalized rainfall (by standard deviation, 11-yr running averages).

\section{Results}

Rainfall variations over the Sahel, Sahelo-Sahara, and Soudan regions are similar (Fig, 2). While oscillations with a period of approximately $25 \mathrm{yr}$ are noted before 1955 , there was a sharp decrease in rainfall after 1955. The rainfall varied from about 0.7 standard deviations to as low as -0.8 . Over Nordeste, the rainfall variation from 1915 to 1930 was quite similar to that of the Sahel and Soudan regions. However, from about 1930 the opposite rainfall variation is seen over subSahara and Nordeste. In particular, the increase in rainfall from about -0.4 standard deviations to +0.4 from around 1955 to 1970 is clearly seen over Nordeste. The negative correlation between the rainfall over the two regions is quite strong. The value of the correlation cocfficients increases when it is calculated for the period 1930-85. All correlation coefficients in Table 1 are significant at the $95 \%$ confidence level by the Student's $t$ test. Correlations between the Nordeste and SaheloSahara regions and between Nordeste and Sahel for the 1930-85 period are significant at the $97.5 \%$ confidence level.

Figure 3 shows the differences between 21 -yr mean fields centered in 1990 and 1959 for the low-level horizontal winds, sea level pressure, and 850 -hPa vertical velocity for the February-May and June-August seasons. There is clear evidence of convergence over Nordeste and divergence over sub-Sahara in the surface wind data during both the austral summer and boreal summer seasons (Figs. 3a.b). There is evidence of an increase in rising motion over Nordeste and a decrease in rising motion over sub-Sahara (Figs. 3c,d) and there is a decrease in sea level pressure over Nordeste and an
TABLF. 1. Correlation coefficients between annual precipitation in sub-Saharan regions and the Nordeste region (column 1) for the available period of data, (column 2) for 1930-85, and (column 3) between annual precipitation in sub-Saharan regions and the ITCZ position in January for 1954-85. The numbers in parentheses are the numbers over which the correlation coefficients are calculated.

\begin{tabular}{lccc}
\hline & Nordeste & $\begin{array}{c}\text { Nordeste } \\
1930-85\end{array}$ & $\begin{array}{c}\text { ITCZ position } \\
\text { in January }\end{array}$ \\
\hline Sahelo-Sahara & $-0.80(60)$ & $-0.83(56)$ & $+0.97(32)$ \\
Sahel & $-0.61(69)$ & $-0.76(56)$ & $+0.93(32)$ \\
Soudan & $-0.60(69)$ & $-0.74(56)$ & $+0.91(32)$ \\
Nordeste & & & $-0.86(32)$ \\
\hline
\end{tabular}

increase over sub-Sahara (Figs. 3e,f). Thus the atmospheric changes between the two periods are consistent with the increase in rainfall over Nordeste and the decrease over sub-Sahara.

Figure 4 shows the long-term variation of sea level pressure over sub-Sahara and Nordeste for FMAM and JJA. It can be seen in Fig. 4a that over sub-Sahara there is a strong tendency for the increase in sea level pressure and over Nordeste there is a slow decrease. Over sub-Sahara and Nordeste in FMAM, the tendencies are, respectively, $+3.77 \mathrm{hPa}(55 \mathrm{yr})^{-1}$ and $-0.53 \mathrm{hPa}$ $(55 \mathrm{yr})^{-1}$. In JJA, the tendencies are $+3.8 \mathrm{hPa}(55 \mathrm{yr})^{-1}$ and $-0.34 \mathrm{hPa}(55 \mathrm{yr})^{-1}$. These values are significant by the Mann-Kendall test. In the 1950s during FMAM, the sea level pressure over sub-Sahara is lower than that over Nordeste. However, from about 1995 on, it is either equal or slightly higher than that over Nordeste. These changes have implications for the observed lowlevel circulation changes. Table 2 shows the lagged correlations in sea level pressure (11-yr means) between sub-Sahara and Nordeste. A minus sign indicates that the rainfall of sub-Sahara lags that of Nordeste. It can be seen that the correlation coefficients are high and negative and do not vary much. We also calculated lagged correlations for the rainfall in the two regions (not shown). In this case, the highest values are found for zero lag. Thus the calculation of lagged corrclations did not help in elucidating the cause and effect relationship. In any case, the correlation coefficients are always strongly negative, suggesting that the inverse relationship between Nordeste and sub-Sahara is robust.

\section{Discussion and conclusions}

Several studies have attributed the Nordeste precipitation variability to the anomalous position of the ITCZ in the Atlantic (c.g., Hastenrath and Heller 1977; Moura and Shukla 1981), which in turn is related to the SST and wind variability in the tropical Atlantic, as well 

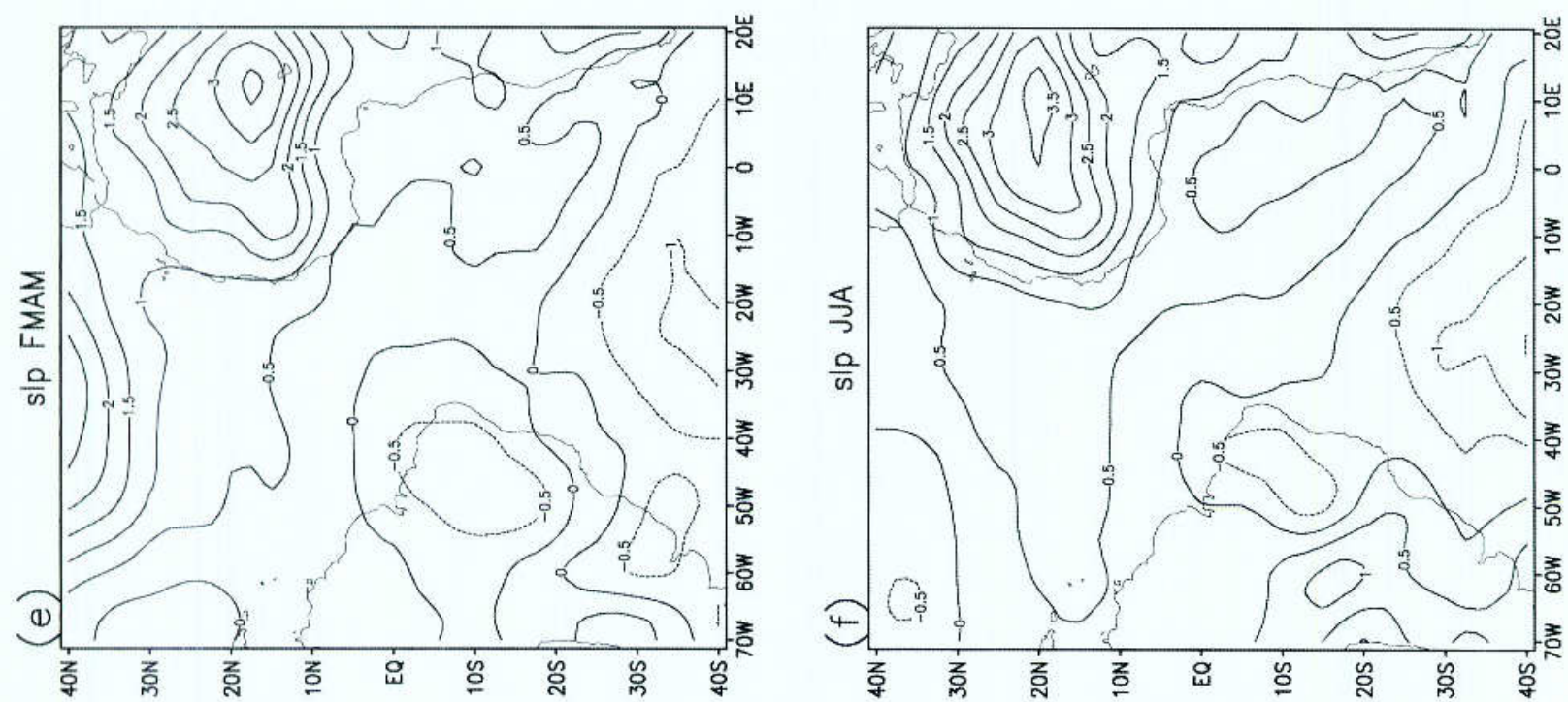

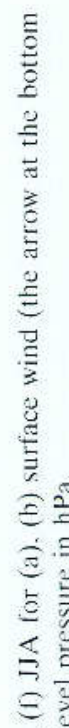
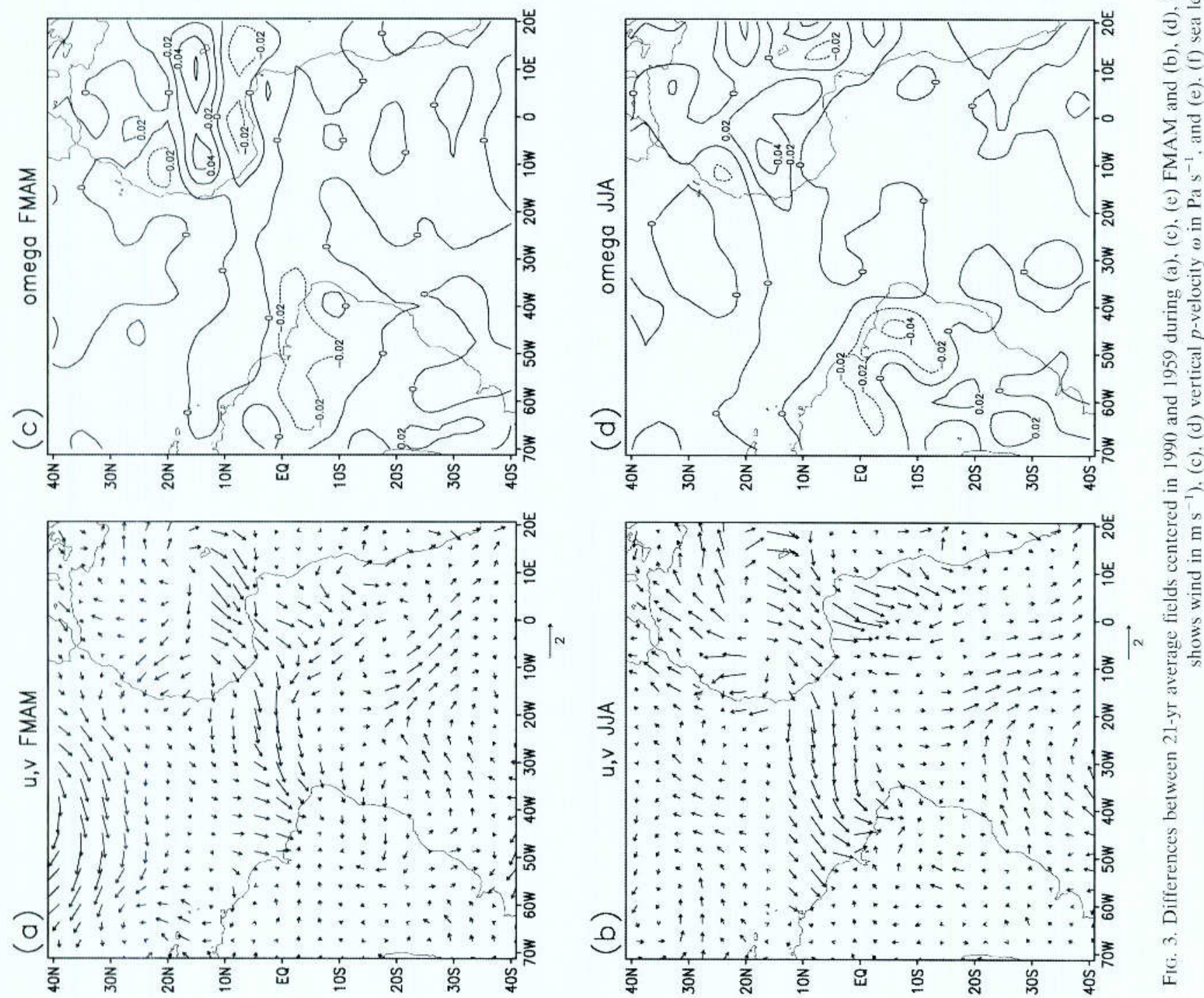
(a) SLP FMAM

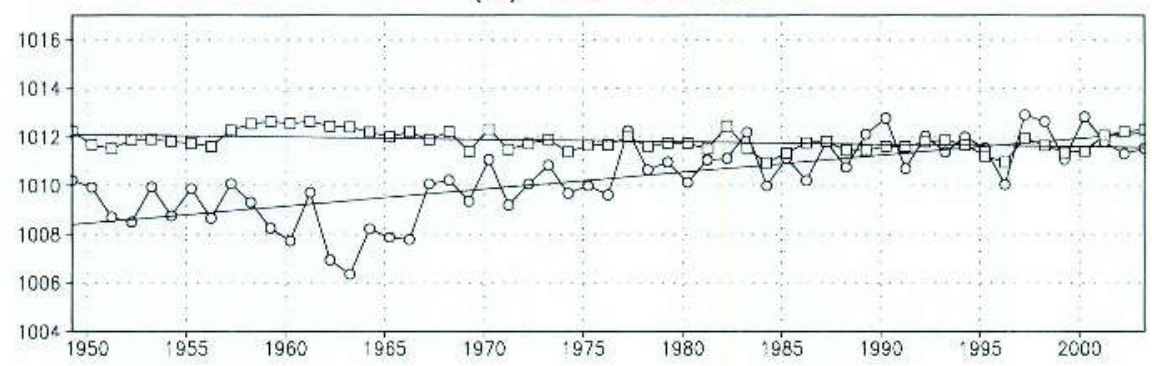

(b) SLP JJA

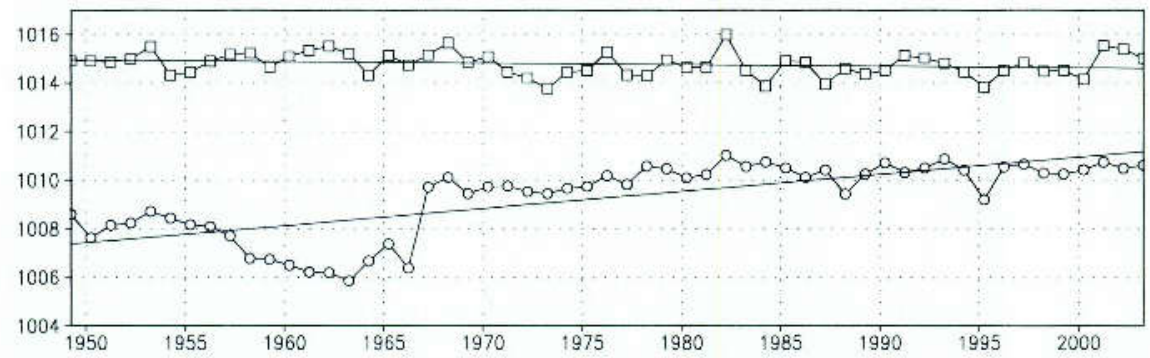

Fig. 4. Variations of sca level pressure in hPa over sub-Sahara and Nordeste during (a) FMAM and (b) JJA. The squares represent Nordeste and the circles represent sub-Sahara.

as to the atmospheric circulation patterns associated with the Hadley and Walker cells. Recently, Hagos and Cook (2005) showed that African surface processes also influence the position of the ITCZ in the Atlantic, which is related to the Nordeste rainfall variations. Here we show that the ITCZ is one of the main mechanisms connecting Nordeste and sub-Saharan precipitation, and that the position of the ITCZ in the Atlantic might also be indicative of the long-term trend of precipitation in these two regions. Cook et al. (2004) attributed the influence of the African continent on South America during both the austral summer and winter seasons to changes in the Walker circulation. Here we showed the importance of the position of the ITCZ, which of course is related to both the Walker and Hadley circulations, for the rainfall variations over the sub-Sahara and Nordeste regions. The meridional displacement of the ITCZ over the tropical Atlantic is such that it has its southernmost position in austral autumn and northernmost position in boreal summer

TABLE 2. Lagged correlations between sub-Sahara and Nordeste for sea level pressure. Lag 1 represents one year for the indicated season.

\begin{tabular}{lccccccc}
\hline \hline & $\begin{array}{c}\text { Lag } \\
-3\end{array}$ & $\begin{array}{c}\text { Lag } \\
-2\end{array}$ & $\begin{array}{c}\text { L.ag } \\
-1\end{array}$ & $\begin{array}{c}\text { L.ag } \\
0\end{array}$ & $\begin{array}{c}\text { Lag } \\
+1\end{array}$ & $\begin{array}{c}\text { Lag } \\
+2\end{array}$ & $\begin{array}{c}\text { Lag } \\
+3\end{array}$ \\
\hline FMAM & -0.89 & -0.93 & -0.96 & -0.97 & -0.98 & -0.98 & -0.96 \\
JJA & -0.89 & -0.92 & -0.93 & -0.92 & -0.91 & -0.89 & -0.86 \\
\hline
\end{tabular}

(Nobre and Shukla 1996). The northernmost and southernmost positions of the ITCZ over the Atlantic coincide, respectively, with the rainfall seasons over the sub-Sahara and Nordeste regions. Also, the orientation of the ITCZ in the Atlantic from northeast to southwest, is in such a way that on the western end it affects the rainfall of Nordeste and on the eastern end it influences sub-Saharan rainfall. The correlation coefficients between the position of the ITCZ at $30^{\circ} \mathrm{W}$ in January and sub-Saharan rainfall are highly positive and significant at $97.5 \%$ (Table 1). A positive (negative) correlation indicates that a more northerly (southerly) position is favorable for higher rainfall over the sub-Sahara (Nordeste) region. The correlation coefficient between the position of the ITCZ in January and rainfall over Nordeste is strongly negative $(-0.85)$ and significant at $95 \%$. The magnitude of this correlation coefficient is considerably larger than that of -0.28 , obtained by Uvo (1989) between the position of the ITCZ at $35^{\circ} \mathrm{W}$ in January and the seasonal Nordeste rainfall. The sign of the correlation coefficient in both studies is the same. However, the difference in magnitude of the correlation coefficients might be due to the difference in the period of analyses. Uvo (1989) used a $17-\mathrm{yr}$ period (1971-87) and here we used the 1948-95 period.

Although the rainfall season over sub-Sahara is in the boreal summer, the correlation between the annual rainfall series used here and the position of the ITCZ at 
$30^{\circ} \mathrm{W}$ in June is very low (the correlation coefficients between the position of the ITCZ and the rainfall over the Sahelo-Sahara, Sahel, and Soudan regions are, respectively, $0.02,-0.24$, and -0.26$)$. Since the correlation coefficients between the annual rainfall over the subSahara and the position of the ITCZ in January are high and significant (Table 1), the position of the ITCZ can be used for the prediction of rainfall over subSahara.

This hypothesis seems to be consistent with Kayano and Andreoli's (2004) findings on the relationship between Nordeste rainfall and SST variations in the tropical Pacific for the decadal scale. They proposed that the negative (positive) phase North Atlantic Oscillation in the North Atlantic region, accompanying a warm (cold) ENSO-like multidecadal mode in the Pacific, affects the subtropical high pressure system and the associated low-level winds, which in turn favor the appearance of positive (negative) SST anomalies in the tropical North Atlantic. As a result, the ITCZ is located more to the north (south) than its normal position, thus creating favorable conditions to reduce (increase) rainfall over northern Nordeste as well as to increase (reduce) rainfall over sub-Sahara.

The results presented here strongly suggest that the increasing trend of rainfall over Nordeste in recent years is related to the decrease in rainfall over subSaharan Africa. A more southward position of ITCZ in the Atlantic seems to be a plausible cause for these changes.

Acknowledgments. We are grateful to Prof. S. Hastenrath and three other reviewers for their critical comments.

\section{REFERENCES}

Cook, K. H., J. S. Hsieh, and S. M. Hagos, 2004: The Africa-South America intercontinental teleconnection. I. Climate, 17, 2851-2865.

Dai, A. G., P. J. Lamb, K. E. Trenberth, M. Hulme, P. D. Jones, and P. P. Xie, 2004: The recent Sahel drought is real. Int. J. Climatol. 24, 1323-1331.

Hagos, S. M., and K. H. Cook, 2005: Influence of surface processes over Africa on the Atlantic marine ITCZ and South American precipitation. J. Climate, 18, 4993-5010.

Hastenrath, S., 1995: Recent advances in tropical climate prediction. I. Climate, 8, 1519-1532.

2000: Interannual and longer-term variability of upper air circulation in the Northeast Brazil-tropical Atlantic sector. $I$. Geophys. Res., 105, 7327-7335.

- and L. Heller, 1977: Dynamics of climatic hazards in northeast Brazil. Quart. I. Roy, Meteor. Soc, 103, 77-92.
_ and L. Greischar, 1993: Circulation mechanisms related to northeast Brazil rainfall anomalies. J. Geophys. Res., 98, $5093-51012$.

Kalnay, E., and Coauthors, 1996: The NCEP/NCAR 40-Year Reanalysis Project. Bull. Amer. Meteor. Soc., 77, 437-471.

Kayano, M. T., and R. V. Andreoli, 2004: Decadal variability of northern northeast Brazil rainfall and its relation to tropical sea surlace temperature and global sea level pressure anomalies. J. Geophys. Res., 109, C11011, doi:10.1029/ 2004JC002429.

Marengo, J. A., J. Tomasella, and C. R. B. Uvo, 1998: Trends in streamflow and rainfall in tropical South America: Amazonia and eastern Brazil, and northwestern Peru. J. Geophys. Res., 103, $1775-1783$.

Moura, A. D., and J. Shukla, 1981: On the dynamics of droughts in northeast Brazil: Observations, theory, and numerical experiments with a general circulation model. J. Atmos. Sci., 38, 2653-2675.

, and S. Hastenrath, 2004: Climate prediction for Brazil's Nordeste: Performance of empirical and numerical modeling methods. J. Climate, 17, 2667-2672.

Nicholson, S. E., 1994: Century-scalc series of standardized annual departures of rainfall. Trends' 93: A Compendium of Data on Global Change, ORNI./CDIAC-65, 1. A. Boden et al., Eds., Carbon Dioxide Information Analysis Center, Oak Ridge National Laboratory, 952-962.

Nobre, P., and J. Shukla, 1996: Variations of sea surface temperature, wind stress, and rainfall over the tropical Atlantic and South America. J. Climate, 9, 2464-2479.

Paegle, J. N., and K. C. Mo, 2002: Linkages between summer rainfall variability over South America and sea surface temperature anomalies. J. Climate, 15, 1389-1407.

Rao, V. B.. K. Hada, and D. Herdies, 1995: On the severe drought of 1993 in Northeast Brazil. Int. J. Climatol., 15, 697-704.

_ S. R. Chapa, and S. H. Franchito, 1999: Decadal variation of atmosphere-ocean in the tropical Atlantic and its relationship to the northeast Brazil rainfall. J. Meteor. Soc. Japan, 77. $63-75$.

, J. P. R. Fernandez, and S. H. Franchito, 2004: Quasistationary waves in the Southern Hemisphere during the El Niño and La Niña events. Ann. Geophys., 22, 789-8(1)6.

Stoeckenius, T., 1981: Interannual variations of tropical precipitation patterns, Mon. Wea. Rev., 109, 1233-1247.

Trewartha, G. T., 1961: The Earth's Problem Climates. University of Wisconsin Press, $334 \mathrm{pp}$.

Uvo, R. C. B., 1989: A zona de convergência intertropical (ZCIT) e sua relaçâo com a precipitação da região norte do nordeste brasileiro (in Portuguese). M.S. dissertation, Department of Meteorology, Instituto Nacional de Pesquisas Espaciais, 99 pp.

Wagner, R. G.. 1996: Decadal-scale trends in mechanisms controlling meridional sea surface temperature gradients in the tropical Atlantic. I. Geophys. Res., 101, 16 683-16 694.

Walker. G. T., 1928: Ceara (Brazil) famines and the general air movement. Beitr. Phys. Atmos, 14, 88-93.

Zhang, C., and H. H. Hendon, 1997: Propagating and standing components of the intraseasonal oscillation in tropical convection. J. Atmos. Sci., 54, 741-752. 


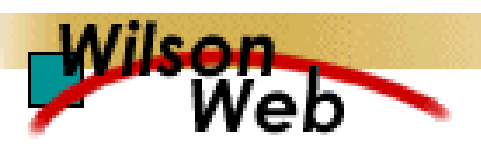

\section{COPYRIGHT INFORMATION}

TITLE: Is the Recent Increasing Trend of Rainfall over Northeast Brazil Related to Sub-Saharan Drought?

SOURCE: J Clim 19 no17 S 12006

WN: 0624407462021

The magazine publisher is the copyright holder of this article and it is reproduced with permission. Further reproduction of this article in violation of the copyright is prohibited.

Copyright 1982-2006 The H.W. Wilson Company. All rights reserved. 